\title{
Historical Papers
}

\section{Communications historiques}

\section{Obituaries/Nécrologie}

Volume 19, numéro 1, 1984

Guelph 1984

URI : https://id.erudit.org/iderudit/030926ar

DOI : https://doi.org/10.7202/030926ar

Aller au sommaire du numéro

Éditeur(s)

The Canadian Historical Association/La Société historique du Canada

ISSN

0068-8878 (imprimé)

1712-9109 (numérique)

Découvrir la revue

Citer cet article

(1984). Obituaries/Nécrologie. Historical Papers / Communications historiques, 19(1), 219-223. https://doi.org/10.7202/030926ar

All rights reserved $\odot$ The Canadian Historical Association/La Société historique du Canada, 1984
Ce document est protégé par la loi sur le droit d'auteur. L’utilisation des services d'Érudit (y compris la reproduction) est assujettie à sa politique d'utilisation que vous pouvez consulter en ligne.

https://apropos.erudit.org/fr/usagers/politique-dutilisation/
Cet article est diffusé et préservé par Érudit.

Érudit est un consortium interuniversitaire sans but lucratif composé de l’Université de Montréal, l’Université Laval et l’Université du Québec à Montréal. Il a pour mission la promotion et la valorisation de la recherche. https://www.erudit.org/fr/ 


\section{Obituaries/Nécrologie}

\section{KEITH MATTHEWS 1938-1984}

Keith Matthews was born in Devon, England. He joined the Memorial University History department in 1967, shortly before finishing his Oxford D.Phil. His thesis, entitled "The West of England-Newfoundland Fisheries" remains a work of outstanding importance in Newfoundland historiography. It sets out the history of the English connection with Newfoundland until the early 19th century in closely argued detail and attacks the historical myths which, though dealt a mortal blow in the thesis, still linger on - the myths of English hostility to permanent settlement, the prohibition of agriculture, and settlers hiding from naval officers. It remains essential reading for any student of the period.

In 1971 Keith became the founding chairman of the Maritime History Group, and was instrumental in negotiating the acquisition of a huge series of British Empire shipping documents form the Registrar of Shipping in Cardiff. These records now form the bulk of the MHG Archives, the largest collection of its kind in Canada. Together with his colleagues in the MHG he participated in the ambitious Atlantic Canada Shipping Project, a highly innovative study of 19th century shipping in the region. The papers resulting from this project firmly established the MHG's reputation as an important centre for maritime history research.

Keith summed up his academic interests as "fish and ships." He lectured and published in both these areas and in the history of Newfoundland. Beyond this strictly academic work he was an active member of an array of committees and societies. At the time of his death he was president of both the Canadian Sub-Commission of the International Commission on Maritime History and the Canadian Society for the Promotion of Nautical Research, and a member of the National Archival Appraisal Board of Canada.

He possessed a vast fund of knowledge on maritime and Newfoundland history, which he made readily available to students and colleagues. Such generosity was characteristic of an intensely social and lively personality which won him many friends.

His unexpected and early death is a serious blow to a department that has suffered more than its fair share of similar misfortunes in recent years. He will be deeply missed by his colleagues for both his scholarly and personal qualities.

J.K. Hiller

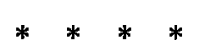

\section{KEITH MATTHEWS 1938-1984}

Né à Devon, en Angleterre, Keith Matthews arrive, en 1967, au Memorial University History Department peu avant de terminer, pour Oxford, sa thèse de doctorat intitulée 


\section{HISTORICAL PAPERS 1984 COMMUNICATIONS HISTORIQUES}

The West of England-Newfoundland Fisheries. Cette étude a marqué d'importance l'historiographie de Terre-Neuve. On y relate de façon détaillée et précise, l'histoire, jusqu'au début du 19e siècle, du lien britannique avec Terre-Neuve et on s'y attaque à des mythes historiques qui, malgré tout, ont survécu à cette tentative de destruction de Matthews: hostilité anglaise à la colonisation, interdiction de l'agriculture, colons se cachant d'officiers navals. Malgré la résistance qu'il a rencontré, ce travail de Matthews est essentiel à tout étudiant(e) de la période.

En 1971, Keith devient président fondateur du Groupe de l'histoire maritime (GMH) et se montre un parfait négociateur dans l'acquisition d'une prestigieuse série de documents sur la navigation dans l'Empire britannique que détenait le Registrar of Shipping de Cardiff. Ces documents font maintenant partie des Archives du GMH, la plus importante collection du genre au Canada. Avec ses collègues du GMH, il participe à l'ambitieux Atlantic Canada Shipping Project, une étude innovatrice de la navigation au $19 \mathrm{e}$ siècle dans la région. Les communications résultant de ce projet ont fermement établi la réputation du GMH comme un important centre de recherche en histoire maritime.

Keith résumait ses intérêts académiques en disant que c'était “'fish and ships". Ses cours et publications portent, en effect, sur la pêche et les navires de même que sur l'histoire de Terre-Neuve. En plus de ce travail académique, il était un membre actif d'une liste prestigieuse de comités et d'associations. Au moment de son décès, il était président de la Sous-commission canadienne de la Commission internationale de l'histoire maritime ainsi que de la Société canadienne pour la promotion de la recherche nautique. Il était, aussi, membre du Conseil national d'évaluation des archives du Canada.

Ses connaissances de l'histoire maritime et de celle de Terre-Neuve étaient impressionnantes et il les rendait disponibles à tous, collègues ou étudiant(e)s. Cette générosité était une des caractéristiques de cette personnalité sociable et vivante, qui se faisant de nombreux et nombreuses ami(e)s.

Son départ inattendu laisse un vide profond dans un département qui a reçu plusieurs coups semblables au cours des dernières années. Il sera profondément regretté par ses collègues autant pour ses qualités académiques que pour ses qualités personnelles.

J.K. Hiller

$* \quad * \quad * \quad *$

\section{LEWIS HERBERT THOMAS 1917-1983}

Lewis Herbert Thomas was born in Saskatoon, Saskatchewan on 13 April 1917, the only child of the Reverend Robert Bremner Thomas and Margaret Ross. His father, a Nova Scotian of Welsh origin, was ordained to the Methodist ministry after a successful career in business and his mother was the daughter of a family originally from the Isle of Skye but long established in Cape Breton.

About 1924 his father accepted a charge in Bermuda but after two years the family returned to Nova Scotia. His parents both died in 1931 and Lewis H. returned to Saskatoon where his paternal aunt, Alice, and her husband, Dr. Herbert Weaver, had 


\section{OBITUARIES/NÉCROLOGIE}

long been established. His high school and university years were thus spent in the Saskatchewan of the depressed thirties. Under the influence of scholars like Arthur Silver Morton, George Simpson and MacGregor Dawson, he graduated from the University of Saskatchewan in 1939 with High Honours in History and Economics.

His eyesight precluded service in the armed forces and he continued his studies in Saskatchewan, receiving his Master of Arts in history in 1941. His thesis, "Constitutional Development of the North-West Territories, 1870-88," was directed by Menzies Whitelaw. After a year in a teacher-training course a fellowship enabled him to spend a year at the University of California. Then a grant to investigate archival facilities in Minnesota and the adjacent states, a project close to the heart of A.S. Morton, took him to the University of Minnesota, where Professor A.L. Burt inspired him to prepare his doctoral dissertation, “The Struggle for Responsible Government in the North-West Territories. " Published in 1956 by the University of Toronto Press with a second edition in 1978, this book remains one of the foundation stones of westem Canadian studies and an important contribution to Canada's national history. His association with Burt was the basis of a continuing friendship and led, in 1975, to the publication of The Renaissance of Canadian History: A Biography of A.L. Burt.

Lewis H. returned to the University of Saskatchewan in 1944 as a research assistant in the Department of History. In 1946 he was appointed Assistant Provincial Archivist of Saskatchewan and in 1948 Provincial Archivist. Under his guidance the Provincial Archives of Saskatchewan emerged in the late 50s as a model of its kind. His work at the Archives was complemented by his editorship of Saskatchewan History from 1949 to 1957.

In 1957 he left the Archives to teach on the Regina campus of the University of Saskatchewan. In his teaching and writing as well as his work as an archivist and editor, he demonstrated his strong sense of the pastoral aspects of his vocation for historical scholarship. In 1964 he joined the Department of History at the University of Alberta. From 1965 to 1968 he served as its chairman and played an important part in the development of the department's offerings in the field of Canadian history. He was also a leader in the establishment of the University of Alberta Archives and an active member of the Historical Society of Alberta in both its Edmonton and Alberta aspects. From 1968 to 1977 he gave distinguished service as Alberta's representative on the Historic Sites and Monuments Board of Canada.

Both in Regina and Edmonton he was supported by a warm and happy family life, and by a host of friends. He and Margaret Eleanor Telford were married in 1946 and their two children, Jean Alice and Robert Telford, were born in Regina. Marriage brought him into close touch with progressive politics in Saskatchewan for the Telfords were stalwarts of the CCF and the NDP. This interest is reflected in one of his last accomplishments, the publication in 1982 of The Making of a Socialist: The Recollections of T.C. Douglas.

A central figure in the scholarly reexamination of western Canada's history by a new generation of Canadian historians, Lewis $\mathrm{H}$. Thomas was awarded the degree of Doctor of Laws by the University of Regina in 1972 and in 1979 he was named an Honourary Life Member of the Canadian Historical Association. In 1983 his colleagues, students and friends presented a festschrift, The Developing West, Essays on Canadian History in 


\section{HISTORICAL PAPERS 1984 COMMUNICATIONS HISTORIQUES}

Honour of Lewis H. Thomas, edited by J.E. Foster. In the same year he was invested with the Order of Canada.

From the time of his move to Edmonton he struggled heroically against debilitating illness but managed to maintain his distinguished contribution to historical scholarship until his death in 1983 in Regina, where he had moved in 1982 after his retirement. He is survived by his wife and two children and remembered with admiration and affection by three generations of Canadians.

Lewis G. Thomas

\section{LEWIS HERBERT THOMAS, 1917-1983}

Lewis Herbert Thomas est né à Saskatoon, Saskatchewan le 13 April 1917. Il est le fils unique du révérend Robert Bremner Thomas et de Margaret Ross. Son père, né en Nouvelle-Ecosse mais d'origine galloise, fut ordonné à l'Église méthodiste après une brillante carrière en affaires et sa mère était issue d'une famille originaire de l'île de Skye, mais établie de longue date au Cap Breton.

Vers 1924 , son père accepta un poste aux Bermudes; deux ans plus tard, la famille était de retour en Nouvelle-Ecosse. Ses parents sont décédés en 1931 et Lewis H. est retourné à Saskatoon où la soeur de son père, Alice, et son mari, le Docteur Herbert Weaver étaient établis depuis longtemps. Il a fait ses études secondaires et universitaires en Saskatchewan, dans les années de la Dépression. Sous l'influence d'hommes de savoir comme Arthur Silver Norton, George Simpson et MacGregor Dawson, il a obtenu son diplôme en histoire et en économie de l'université de Saskatchewan en 1939, avec grande distinction.

Les problèmes de la vue dont il était affecté l'ont empêché de servir dans les forces armées et il a poursuivi ses études en Saskatchewan, pour recevoir une maîtrise ès arts en histoire, en 1941. Menzies Whitelaw fut le directeur de sa thèse intitulée Constitutional Development of the North-West Territories, 1870-1888. Après avoir suivi un cours de formation pédagogique d'un an, il a reçu une bourse de recherche qui lui a permis de passer une année à l'université de Californie. Par la suite, il s'est vu attribuer une subvention pour étudier les dépôts d'archives du Minnesota et des états avoisinants, un projet cher au coeur de A.S. Morton. Ce travail l'a conduit à l'université du Minnesota, où le professeur A.L. Burt l'a inspiré dans la préparation de sa thèse de doctorat The Struggle for Responsible Government in the North-West Territories. Publié en 1956 par les presses de l'université de Toronto, avec une deuxième édition en 1978, cet ouvrage demeure l'une des grandes études sur l'Ouest canadien et une contribution importante à notre histoire nationale. Son association avec Burt a doné lieu à une amitié durable et à la publication, en 1975, de The Renaissance of Canadian History: A Biography of A.L. Burt.

Lewis H. est retourné à l'université de la Saskatchewan, en 1944, comme adjoint à la recherche à la Faculté d'histoire. En 1946, il a été nommé archiviste provincial adjoint de la Saskatchewan et archiviste provincial en 1948. Sous sa direction, les archives provin- 


\section{OBITUARIES/NÉCROLOGIE}

ciales de la Saskatchewan sont devenues, à la fin des années 50, un modèle dans le domaine. Il fut aussi rédacteur de Saskatchewan History, de 1949 à 1957.

En 1957, il a quitté les archives pour enseigner au campus Régina de l'université de la Saskatchewan. Que ce soit dans l'enseignement et l'écriture ou dans le domaine des archives et de la rédaction, il a démontré une compréhension solide de l'aspect "pastoral" de sa vocation. En 1964, il a joint les rangs de la faculté d'histoire de l'université de l'Alberta. De 1965 à 1968, il y a rempli les fonctions de président et il a joué un rôle important dans le développement des contributions de la faculté à l'histoire canadienne. Il a également été un leader dans la constitution des archives de l'université de l'Alberta et un membre actif de la Historical Society of Alberta. De 1968 à 1977, il s'est distingué en tant que représentant de l'Alberta auprès de la Commission des sites historiques du Canada.

A Régina et à Edmonton, il jouissait d'une vie de famille heureuse et réconfortante; il y était aussi entouré d'un bon groupe d'amis. Margaret Eleanor Telford et lui se sont mariés en 1946 et leurs deux enfants, Jean Alice et Robert Telford, son nées à Régina. Le mariage l'a mêlé de près à la politique progressiste en Saskatchewan, car les Telford étaient de solides partisans du CCF et du NDP. Cet intérêt est manifeste dans l'une de ses dernières réalisations: la publication, en 1982, de The Making of a Socialist: The Recollections of T.C. Douglas.

Comme figure centrale du réexamen érudit de l'histoire de l'Ouest du pays par une nouvelle génération d'historiens canadiens, Lewis $\mathbf{H}$. Thomas s'est vu décerner, en 1972, le grade de docteur en droit par l'université de Régina et, en 1979, il a été nommé membre honoraire à vie de la Société historique du Canada. En 1983, ses collègues, étudiants et amis lui on présenté un festschrift, The Developing West, Essays on Canadian History in Honour of Lewis H. Thomas, rédigé par J.E. Foster. La même année, il a été décoré de l'Ordre du Canada.

A partir de son arrivée à Edmonton, malgré le combat acharné qu'il menait contre la maladie, il s'est fait un point d'honneur de continuer à contribuer au savoir historique jusqu'à sa mort en 1983, à Régina, où il avait élu domicile, après sa retraite, en 1982. Sa femme et ses deux enfant lui survivent, et trois générations de Canadiens lui vouent admiration et affection.

Lewis G. Thomas 